DOI: https://doi.org/10.24127/ajpm.v10i4.4289

\title{
ANALISIS KEMAMPUAN PEMAHAMAN KONSEP MATEMATIS DAN KESALAHAN MENYELESAIKAN SOAL CERITA MENGGUNAKAN PROSEDUR NEWMAN
}

\author{
Tahir $^{1^{*}}$, Marniati ${ }^{2}$ \\ ${ }^{1 * 2}$ Universitas Sembilanbelas November Kolaka, Kolaka, Indonesia \\ *Corresponding author. \\ E-mail: $\quad \frac{\text { tahir.anwar.ta89@gmail.com }}{\left.{ }^{*}\right)}$ \\ bungaitb@gmail.com $^{2)}$
}

Received 15 November 2021; Received in revised form 15 November 2021; Accepted 28 December 2021

\begin{abstract}
Abstrak
Penelitian dilakukan dengan tujuan untuk melihat kemapuan pemahaman konsep matematis siswa dan kesalahan-kesalahan yang dilakukan dalam menyelesaikan soal cerita pada materi pecahan dengan prosedur Newman. Jenis penelitian ini adalah penelitian deskriftip yang dilaksanakan pada SD Negeri dikecamatan lalolae. Subjek Pada penelitian ini adalah siswa kelas V 54. Instrumen yang digunakan dalam penelitian ini adalah tes essai yang dikembangkan dan diuji kelayakannya. Dari hasil penelitian yang dilakukan, dari 54 siswa sebagai subjek penelitian diperoleh nilai rata-rata kemampuan pemhaman konsep siswa adalah 41,48 atau berada pada kategori rendah. Dari hasil pengkategorian kemampuan pemahaman konsep siswa mayoritas siswa memiliki kemampuan pemahaman konsep pada kriteria rendah serta sangat rendah dengan total $74 \%$ serta kategori sangat rendah menyumbang sebesar $43 \%$. Selanjutnya dari hasil analisis kesalahan siswa menggunakan prosedur Newman, siswa melakukan 215 kesalahan dengan kesalahan terbanyak yang dilakukan siswa adalah Comprehension errors.
\end{abstract}

Kata kunci: Kesalahan mengerjakan soal; pemahaman konsep matematis; prosedur Newman.

\begin{abstract}
The research was conducted with the aim of looking at the ability to understand students' mathematical concepts and the mistakes made in solving story problems on fractions using the Newman procedure. This type of research is descriptive research which was carried out at a public elementary school in the Lalolae district. The subjects in this study were students of class V 54. The instrument used in this study was an essay test which was developed and tested for feasibility. From the results of the research conducted, from 54 students as research subjects, the average value of students' conceptual understanding ability was 41.48 or was in the low category. From the results of the categorization of students' conceptual understanding abilities, the majority of students have the ability to understand concepts on low and very low criteria with a total of $74 \%$ and very low categories account for $43 \%$. Furthermore, from the results of student error analysis using the Newman procedure, students made 215 errors with the most errors made by students were Comprehension errors.
\end{abstract}

Keywords: Keywords; error working on the problem, understanding mathematical concepts, Newman procedure.

This is an open access article under the Creative Commons Attribution 4.0 International License

\section{PENDAHULUAN}

Pandemi Covid 19 membawa dampak pada dunia pendidikan, salah satunya adalah dengan diterapkannya pembelajaran online (Sobana, 2020).
Pembelajaran online membuat guru tidak dapat memberi pembelajaran yang maksimal kepada siswa terutama untuk sekolah-sekolah di desa. Sehingga 
berdapak pada pemahaman konsep pembelajaran (Siahaan et al., 2020).

Matematika merupakan salah satu mata pelajaran dengan salah satu tujuan utamanya adalah membuat siswa memahami konsep (Rahmadhani \& Wahyuni, 2021; Setyaningrum, Hendikawati, and Nugroho, 2018). Hal ini disebabkan karena belajar matematika itu belajar secara berkesinambungan (Abrar, 2018). Maka jika kemampuan pemahaman konsep siswa rendah maka siswa akan kesusahan belajar matematika kedepannya (Astuti, Yusmin, and Suratman, 2015; Jarmita, 2014).

$$
\text { Realitanya kemampuan }
$$

pemahaman konsep siswa saat ini masih rendah. Beberapa penelitian mengenai pemahaman konsep seperti Yuliani (2018); Fajar et al. (2019) yang juga menyimpulkan bahwa hasil kemampuan pemahaman konsep siswa pada kategori rendah. Untuk skala yang lebih besar hasil survei yang dilakukan oleh TIMSS juga berkesimpulan masih banyak siswa mengalami kesulitan dalam memahami konsep-konsep matematika (Cahani and Effendi, 2019). Namun penelitianpenelitian tersebut dilakukan pada tingkat sekolah menengah dan hanya berfokus pada kemampuan pemahaman konsepnya, tidak melakukan evaluasi lebih lanjut mengenai kesalahan yang dilakukan siswa sehingga kemampuan konsepnya rendah. Sedangkan penanaman konsep matematika harusnya sudah dimulai pada sekolah dasar (Wulandari, 2012). Serta sebaiknya kita mengetahui kesalahankesalahan siwa dalam mengerjakan soal untuk bisa dicari solusinya.

Seperti pada siswa SD di kec. Lalolae, dari observasi dan wawancara yang dilakukan pada tanggal 10 oktober 2020 diperoleh hasil informasi bahwa kemampuan pemahaman konsep siswa masih kurang hal ini terdeteksi dari masih banyak siswa yang mengalami kesusahan untuk menyelesaikan soalsoal matematika khususnya untuk soal cerita, kesalahan-kesalahan yang dilakukan seperti salah memahami soal ataupun salah menggunkan prosedur penyelesaian. Kebanyakan siswa belum bisa menyelesaikan soal karena belum memahami masalah (Rudtin, 2013). Sedangkan Fitriatien (2019) menyatakan kesalahan siswa sering melakukan kesalahan dalam mengubah permasalahan ke dalam model matematika yang mana kesalahan ini disebut kesalahan fakta.

Sehingga diperlukan suatu penelitian untuk menilai kesalahankesalahn yang dilakukan siswa dalam menyelesaikan soal. Prosedur Newman adalah salah satu prosedur yang dapat digunakan untuk melakukan penilaian terhadap kesalahan yang dilakukan siswa dalam menyelesaikan soal terutama soal cerita (Amalia, 2019; Puspitasari \& Zulkarnaen, 2021). Sebab prosedur Newman ini memudahkan dalam menganalisis kesalahan karena memiliki lima tahapan yang dilewati siswa saat memecahkan masalah yaitu readin, comprehension, transformation, process skill, encoding (Oktaviana, 2018; Siswandi \& Sujadi, 2016).

Berdasarkan pembahasan di atas maka perlu diadakan penelitian untuk menganalisis kemampuan pemahaman konsep dan kesalahan siswa dalam menyelesaikan soal pada materi pecahan dengan prosedur Newman. Agar diperoleh informasi akurat, yang dapat mendukung langkah selanjutnya.

\section{METODE PENELITIAN}

Penelitian ini adalah penelitian deskriptif dengan tahapan penelitian ini yaitu: menentukan subjek penelitian, membuat instrumen penelitian yang 
DOI: https://doi.org/10.24127/ajpm.v10i4.4289

sesuai dengan semua indikator pemahaman konsep yang akan diukur, memberi instrumen tes kepada subjek penelitian berupa soal cerita pada materi pecahan yang disusun sesuai indikator kemampuan pemahan konsep matematis. melakukan analisi kemampuan pemahaman konsep, melakukan analisis kesalahan siswa dengan prosedur newman, melakukan wawancara kepada subjek penelitian, pengolahan data sesuai dengan indikator kemampuan pemahaman konsep dan prosedur newman.

\section{Subjek Penelitian}

Subjek Pada penelitian ini adalah siswa kelas V di SD Negeri yang berada di kecamatan Lalolae berjumlah 54 orang siswa yang dipilih dengan menggunakan purposive sampling.

\section{Metode Pengumpulan Data}

Data pada penelitian ini dikumpulkan melalui 2 cara yaitu metode pemberian tes dan wawancara, soal instrumen tes yang diberikan adalah soal esay berbentuk soal cerita yang terlebih dahulu diuji cobakan dan diuji validitas, reabilitas, tingkat kesukaran dan daya pembedanya. Tujuan pemberian instrumen tes untuk mengukur kemampuan pemahaman konsep dan kesalahan siswa dalam menyelesaikan soal cerita yang diberikan. Sedangkan wawancara dilakukan untuk menggali lebih dalam informasi dari subjek penelitian. Berikut hasil analisis uji coba instrumen.

Tabel 1. Hasil uji validitas tes

\begin{tabular}{cccc}
\hline No. & $r_{\text {hit }}$ & $r_{\text {tab }}$ & ket \\
\hline 1 & 0,3358 & & Tidak Valid \\
2 & 0,7190 & & Valid \\
3 & 0,6493 & 0,36 & Valid \\
4 & 0,7812 & & Valid \\
5 & 0,3565 & & Tidak Valid \\
\hline
\end{tabular}

Dari Tabel 1 diperoleh bahwa soal nomor 1 dan 5 tidak valid untuk digunakan, sedangkan soal nomor 2, 3 dan 4 valid. Selanjutnya diuji tingkat reabilitas tes untuk soal no 2,3 dan 4 menggunakan Uji reliabilitas dapat menggunakan rumus Cronbach's Alpha ( $\alpha$ ) (Hendriana, 2014) dan diperoleh hasil $R_{11}=0,6767$ nilai ini beerada pada kategori reliabilitas tinggi. Selanjutnya hasil perhitungan tingkat kesukaran dan daya pembeda dapat dilihat pada Tabel 2 .

Tabel 2. Hasil perhitungan indeks kesukaran dan daya pembeda soal

\begin{tabular}{ccccc}
\hline No. Soal & Indek Kesukaran & Kriteria & Daya Pembeda & Kriteria \\
\hline 2 & 0,6417 & Sedang & 2,8667 & Cukup \\
3 & 0,5833 & Sedang & 2,4 & Cukup \\
4 & 0,21667 & Sukar & 2,9333 & Cukup \\
\hline
\end{tabular}

\section{Analisis Data}

Hasil tes siswa dinilai sesuai dengan penilaian masing-masing indikator kemampuan pemahaman konsep, sesuai dengan rubrik penilaian untuk kemampuan pemahaman konsep. data yang diperoleh selanjutnya dianalisis secara deskriptif. Dimulai dengan menghitung statistik deskriptif data berupa nilai tertinggi, nilai terendah, rata-rata, median, modus, dan varians. Selanjutnya mengklasifikasikan kemampuan pemahaman konsep siswa sesuai Tabel 3. 
DOI: https://doi.org/10.24127/ajpm.v10i4.4289

Tabel 3. Klasifikasi kemampuan pemahaman konsep.

\begin{tabular}{cc}
\hline Nilai & Kriteria \\
\hline $85 \leq N \leq 100$ & Sangat Baik \\
$70 \leq N<85$ & Baik \\
$55 \leq N<70$ & Cukup \\
$40 \leq N<55$ & Rendah \\
$N<40$ & Sangat Rendah \\
\hline (Mawaddah \& Maryanti, 2016)
\end{tabular}

Setelah itu dilakukan analisis perindikator, untuk melihat kemampuan siswa setiap indikatornya. Selanjutnya untuk melihat kesalahan siswa dalam mengerjakan soal cerita, jawaban siswa dianalisis dengan indikator pada prosedur newman untuk melihat jenisjenis kesalahan yang dilakukan oleh siswa meliputi reading errors, comprehension errors, comprehension errors, transformation errors, process skill errors, encoding errors (Rahmawati \& Permata, 2018).

\section{HASIL DAN PEMBAHASAN}

Hasil tes siswa tersebut dianalisis menggunakan indikator kemampuan pemahaman konsep untuk mengetahui kemampuan pemahaman konsepnya dan dianalisis menggunakan metode Newman untuk melihat kesalahan siswa dalam mengerjakan soal tersebut. Hasil analisis deskriptif kemampuan pemahaman konsep siswa dapat dilihat pada gambar Tabel 4.

Tabel 4. Hasil analisis deskriptif. kemampuan pemahaman konsep siswa

\begin{tabular}{lc}
\hline Statistik & Nilai \\
\hline Mean & 41,48 \\
Standard Error & 2,41 \\
Median & 42,50 \\
Mode & 45,00 \\
Standard Deviation & 17,71 \\
Sample Variance & 313,80 \\
Range & 60,00 \\
Minimum & 15,00 \\
Maximum & 75,00 \\
Sum & 2240,00 \\
Count & 54,00 \\
\hline
\end{tabular}

Berdasarkan Tabel 4. Yang merupakan hasil perhitungan analisis deskriptif yang dilakukan, diperoleh bahwa nilai terendah kemampuan pemahaman konsep siswa adalah 15 dan nilai tertinggi 75 dengan rata-rata nilai 41,48. Nilai siswa terbanyak adalah nilai 45. Selanjutnya hasil analisis nilai siswa tersebut di klasifikasi berdasarkan kriteria kemampuan pemahaman konsep yang dikutip dari Mawaddah and Maryanti (2016) . hasil dari klasifikasi tersebut dapat dilahat pada Tabel 5.

Tabel 5. Hasil klasifikasi kemampuan pemahaman konsep siswa

\begin{tabular}{ccccc}
\hline No & Rentang Nilai & Kriteria & Jumlah & Persentase \\
\hline 1 & $X \geq 85$ & Sangat Baik & 0 & $0 \%$ \\
2 & $70 \leq X<85$ & Baik & 5 & $9 \%$ \\
3 & $55 \leq X<70$ & Cukup & 9 & $17 \%$ \\
4 & $40 \leq X<55$ & Rendah & 17 & $31 \%$ \\
5 & $X<40$ & Sangat Rendah & 23 & $43 \%$ \\
\hline
\end{tabular}

Dari Tabel 5, diperoleh bahwa mayoritas siswa memiliki kemampuan pemahaman konsep pada kategori rendah dengan persentase $31 \%$ dan sangat rendah dengan persentase $43 \%$ yang mana jika digabungkan diperoleh persentase sebesar $74 \%$. nilai $43 \%$ pada kategori sangat rendah ini memberi arti 
DOI: https://doi.org/10.24127/ajpm.v10i4.4289

hampir setengah dari siswa memiliki kemampuan pemahaman konsep berkategori sangat rendah. Jika kita melihat nilai rata-rata yang diperoleh pada tabel sebelumnya yaitu sebesar 41,4815 maka nilai ini masuk pada kategori rendah sehingga dapat disimpulkan bahwa kemampuan pemahaman konsep matematis siswa kelas V pada SD Negeri di kecamatan Lalolae berkategori rendah. Hasil ini sejalan dengan hasil penelitian dari Elza Nora Yuliani (2018); Fajar et al. (2019), yang juga menyimpulkan bahwa hasil kemampuan pemahaman konsep siswa pada kategori rendah. Sedangkan kita tahu bahwa jika kemampuan pemahaman konsep siswa rendah maka siswa akan kesusahan belajar matematika kedepannya (Elfi Rahmadhani, Septia Wahyuni, 2021).

Selanjutnya dilakukan analisis untuk tiap-tiap indikator untuk mengetahui pada indikator mana siswa kurang dalam kemampuan pemahaman konsep matematis. Hasil analisis tersebut dapat dilihat pada Tabel 6.

Tabel 6. Kriteria kemampuan pemahaman konsep siswa perindikator

\begin{tabular}{|c|c|c|c|}
\hline No & Indikator & Nilai Rata-rata & Kategori \\
\hline 1 & Menyatakan ulang sebuah konsep & 72,222 & Baik \\
\hline 2 & $\begin{array}{l}\text { Mengklasifikasikan objek-objek menurut } \\
\text { sifat-sifat tertentu }\end{array}$ & 50 & Rendah \\
\hline 3 & $\begin{array}{l}\text { Menyajikankan konsep dalam berbagai } \\
\text { bentuk representasi matematis }\end{array}$ & 35,6482 & $\begin{array}{l}\text { Sangat } \\
\text { Rendah }\end{array}$ \\
\hline 4 & $\begin{array}{l}\text { Mengaplikasikan konsep atau algoritma } \\
\text { dalam pemecahan masalah }\end{array}$ & 24,7685 & $\begin{array}{l}\text { Sangat } \\
\text { Rendah }\end{array}$ \\
\hline
\end{tabular}

Berdasarkan Tabel 6, diperoleh informasi bahwa pada indikator menyatakan ulang konsep rata-rata siswa menguasainya ini dilihat dari nilai rata-ratanya yang berada pada kategori baik. Untuk indikator mengklasifikasikan objek-objek menurut sifat-sifat tertentu secara ratarata siswa berada pada kategori kurang. Selanjutnya untuk pada indikator menyajikankan konsep dalam berbagai bentuk representasi matematis dan mengaplikasikan konsep atau algoritma dalam pemecahan masalah rata-rata siswa berada pada kategori sangat rendah. Hasil ini menunjukkan bahwa siswa kelas V pada SD Negeri di Kecamatan Lalolae masih sangat minim kemampuannya dalam menklasifikasikan, menyajikan maupun mengaplikasikan konsep hal ini akan berpengaruh pada kemampuan siswa dalam menyelesaikan maslahah matematika. Rendahnya kemampuan siswa dalam aspek pemahaman konsep merupakan hal penting yang harus ditindaklanjuti (Elza Nora Yuliani, 2018).

Selanjutnya untuk melihat kesalahan-kesalahan apa saja yang dilakukan siswa dalam menyelesaikan soal kemampuan pemahaman konsep yang dibuat dalam soal cerita maka dilakukan analisis menggunakan metode newman. Berikut beberapa contoh kesalahan yang dilakukan siswa dalam mengerjakan soal cerita yang diberikan.

\section{Reading errors}

Contoh kesalahan yang dilakukan siswa yang masuk dalam kategori reading errors dapat dilihat pada Gambar 1. 
DOI: https://doi.org/10.24127/ajpm.v10i4.4289

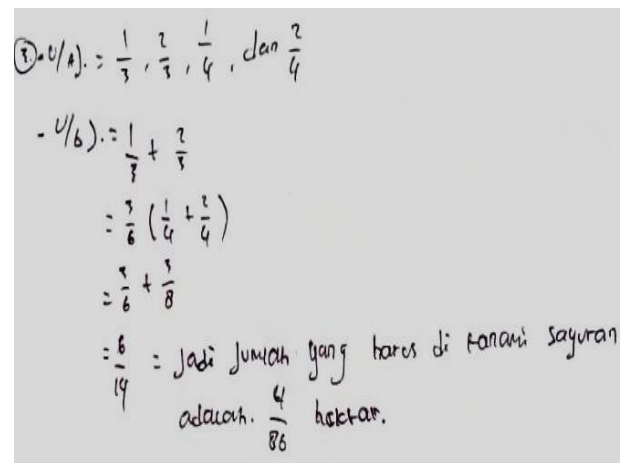

Gambar 1. Contoh reading errors

Pada Gambar 1 tampak bahwa siswa tidak menggunakan informasi pada soal untuk menyelesaikan soal. seharusnya pda soal no. 3 Pak ali memiliki 8 hektar tanah, $2 \frac{2}{3}$ hektar ditanami jagung, $2 \frac{1}{4}$ hektar ditanami padi, $2 \frac{1}{3}$ hektar ditanami ubi dan sisanya ditanami sayur-sayuran. Tetapi siswa tdk mampu memanfaatkan yang diketahui.

\section{Comprehension errors}

Contoh kesalahan yang dilakukan siswa yang masuk dalam kategori comprehension errors disajikan pada Gambar 2.

$$
\begin{aligned}
& \text { 2) a. Yang Merupakan pecahan biasa adalah } \\
& \frac{3}{4} \text { Jam dan } \frac{11}{5} \text { Jam } \\
& \text { Pecahan compuran adalah } 1 \frac{1}{3} \\
& \text { b. } \frac{3}{4} \text { Jam }+\frac{11}{5} \text { Jam }+1 \frac{1}{2}=
\end{aligned}
$$

Gambar 2. Contoh comprehension errors

Pada Gambar 2, siswa tidak dapat memproses lebih lanjut solusi dari permasalahan.

\section{Transformation errors}

Contoh kesalahan yang dilakukan siswa yang masuk dalam kategori transformation errors disajikan pada Gambar 3.

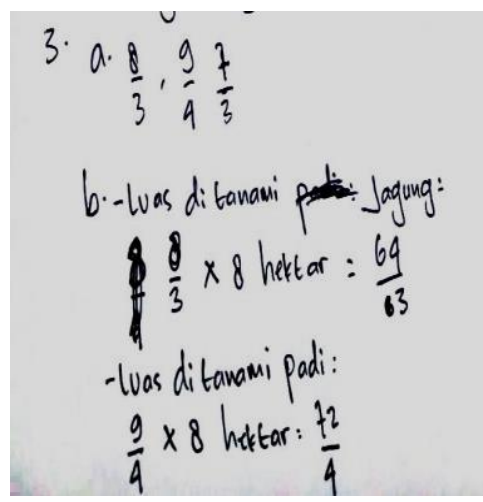

Gambar 3. Contoh transformation errors

Pada Gambar 3 siswa gagal dalam memahami soal-soal untuk diubah kedalam kalimat matematika yang benar.

\section{Process skill errors}

Contoh kesalahan yang dilakukan siswa yang masuk dalam kategori Process skill errors disajikan pada Gambar 4.

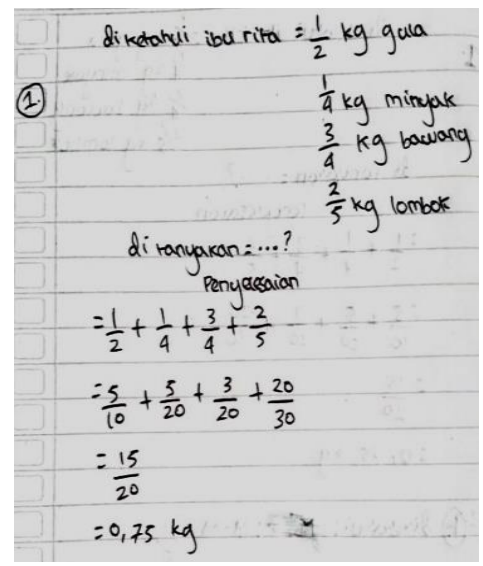

Gambar 4. Contoh process skill errors

Pada Gambar 4, siswa salah dalam menyamakan penyebut pecahan.

\section{Encoding errors}

Contoh kesalahan yang dilakukan siswa yang masuk dalam kategori Process skill errors dapat dilihat pada Gambar 5. Pada Gambar 5, siswa melakukan kesalahan penulisan hasil akhir 
DOI: https://doi.org/10.24127/ajpm.v10i4.4289

$$
\text { b) } \begin{aligned}
\frac{3}{4}+\frac{11}{5}+1 \frac{1}{2} & =\frac{3}{4}+\frac{11}{5}+\frac{1 \times 2+1}{2} \\
& =\frac{3}{4}+\frac{11}{5}+\frac{3}{2} \\
& =\frac{15+44+30}{20} \\
& =\frac{90}{20}
\end{aligned}
$$

Dari hasil analisis kesalahan siswa dengan menggunakan prosedur newman diperoleh bahwa dari 54 orang siswa yang digunakan sebagai subjek penelitian, siswa melakukan kesalahan sebanyak 215 kesalahan dengan rincian dapat dilihat pada Gambar 7.

Gambar 5. Contoh encoding errors
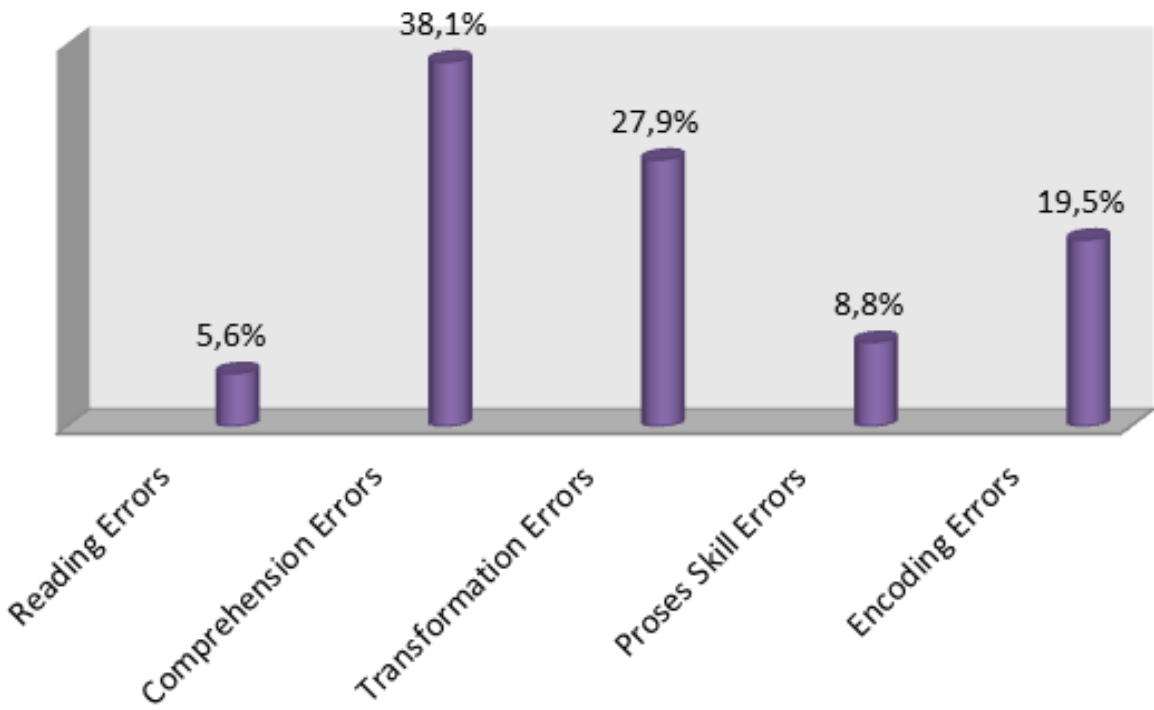

Gambar 6. Hasil analisis kesalahan siswa berdasarkan metode Newman

Dari Gambar 6 tampak bahwa siswa paling banyak melakukan kesalahan pada Comprehension atau memahami masalah dimana pemahaman terhadap masalah merupakan salah satu indikator yang sangat penting sebab tanpa memahami masalah maka siswa akan kesusahan dalam menentukan langka yang harus diambil dalam menyelesaikan soal. Menurut Rudtin (2013) kebanyakan siswa tidak dapat menyelesaikan soal karena tidak memahami masalah. Selanjutnya bentuk kesalahan terbesar kedua adalah kesalahan transformasi atau transformasi errors hal ini sejalan dengan penemuan Fitriatien (2019) bahwa Kesalahan yang sering dilakukan adalah kesalahan fakta, dimana siswa melakukan kesalahan dalam mengubah permasalahan ke dalam model matematika. Sedangkan jika kita melihat di gambar persentase kesalahan terendah adalah reading errors atau kesalahan dalam membaca atau menemukan informasi.

Dari hasil penelitian yang dilakukan diperoleh bahwa rata-rata kemampuan pemahaman konsep siswa kelas V SD di Kec. Lalolae masih rendah bahkan dari 54 orang sampel yang diteliti untuk dianalisis kemampuan pemahaman konsepnya $43 \%$ diantaranya masih memiliki kemampuan pemahaman konsep yang sangat rendah dengan indikator terlemah yaitu Menyajikankan konsep dalam berbagai bentuk representasi matematis dan Mengaplikasikan konsep atau algoritma dalam pemecahan 
masalah hasil ini sejalan dengan hasil penelitian yang dilakukan oleh Yuliani (2018) dan Fajar et al. (2019) yang juga berkesimpilan sama. Selanjutnya dilakukan analisis lebih lanjut untuk mengetahui penyebab hal itu terjadi dengan melakukan analisis kesalahan siswa dengan menggunakan metode Newmann. Dari hasil analisis diperoleh bahwa dari lima jenis kesalahan yang dilakukan siswa dalam menjawab soal yang diberikan, kesalahan terbanyak yang dilakukan siswa adalah Comprehension errors atau Kesalahan dalam memahami masalah yaitu sebesar $38,1 \%$. selanjutnya dilakukan wawancara dengan siswa untuk mengetahui kenapa siswa menjadi susah dalam memahami masalah dari soal yang diberikan. dari hasil wawancara kebanyakan siswa mengaku sangat sulit dalam memahami masalah yang diberikan hal ini dikarenakan guru sangat jarang memberi soal cerita, ataupun menjelaskan secara detail tentang cara menyelesaikan soal, sangat jarang dituliskan yang diketahui dan kesimpulan terutama selama siswa melakukan pembelajaran daring. Selama pembelajaran daring menurut siswa guru hanya memberi buku paket dan menyuruh siswa mempelajari di rumah lalu mengerjakan soal latihan, tanpa diberi penjelasan.

Dari pembahasan di atas dapat dilihat bahwa salah satu penyebab rendahnya kemampuan pemahaman konsep siswa adalah metode pembelajaran yang digunakan oleh guru. Sehingga hasil penelitian ini diharapkan dapat menjadi dasar untuk guru ataupun peneliti selanjutnya untuk mengembangkan model pembelajaran yang tepat untuk meningkatkan kemampuan pemahaman konsep siswa, terutama pada masa pandemi saat ini.

\section{KESIMPULAN DAN SARAN}

Dari hasil penelitian yang dilakukan, dari 54 orang siswa yang digunakan sebagai subjek penelitian diperoleh nilai rata-rata kemampuan pemahaman konsep siswa adalah 41,48 atau berada pada kategori rendah. Dari hasil pengkategorian kemampuan pemahaman konsep siswa mayoritas siswa memiliki kemampuan pemahaman konsep pada kategori rendah dan sangat rendah dengan total 74\% serta kategori sangat rendah menyumbang sebesar $43 \%$. Selanjutnya dari hasil analisis kesalahan siswa menggunakan prosedur Newman, siswa melakukan 215 kesalahan dengan kesalahan terbanyak yang dilakukan siswa adalah Comprehension errors.

Untuk peneliti selanjutnya diharapkan dapat menerapkan suatu model pembelajran ataupun mengembangkan media pembelajan yang tepat untuk meningkatkan kemampuan pemahaman konsep dan meminimalisir kesalahan siswa dalam mengerjakan soal.

\section{DAFTAR PUSTAKA}

Abrar, A., Ika P. (2018). "Jenis-Jenis Belajar Matematika." $A l$ Khwarizmi: Jurnal Pendidikan Matematika Dan Ilmu Pengetahuan Alam 3(1):51-62. doi: 10.24256/jpmipa.v3i1.218.

Amalia, Y. (2019). "Soal Matematika Pada Materi Peluang Kelas Xi." Genta Mulia X(1):11-22.

Astuti, Fitri, N., Edy, Y., \& Dede S. (2015). "Analisis Kesulitan Pemahaman Konseptual Siswa Dalam Menyelesaikan Soal Pada Materi Peluang Di Man Sanggau." Jurnal Pendidikan Dan Pembelajaran 4(10):1-10.

Cahani, K.,\& Kiki, N. S. E. (2019). 
DOI: https://doi.org/10.24127/ajpm.v10i4.4289

"Kemampuan Pemahaman Konsep Matematika Siswa SMP Kelas IX Pada Materi Bangun Datar Segiempat." Prosiding Seminar Nasional Matematika Dan Pendidikan Matematika Sesiomadika 2019 (2008):120-28.

Elza, N. Y., \& Zulfah. (2018). "Kemampuan Pemahaman Konsep Matematis Siswa Kelas Viii Smpn 1 Kuok Melalui Model Pembelajaran." Jurnal Cendekia: Jurnal Pendidikan Matematika 2(2):91-100.

Fajar, A. P., Kodirun K., Suhar, S., \& La, A. (2019). "Analisis Kemampuan Pemahaman Konsep Matematis Siswa Kelas VIII SMP Negeri 17 Kendari." Jurnal Pendidikan Matematika 9(2):229. doi: 10.36709/jpm.v9i2.5872.

Fitriatien, S. R. (2019). "Analisis Kesalahan Dalam Menyelesaikan Soal Cerita Matematika Berdasarkan Newman." JIPMat 4(1). doi: 10.26877/jipmat.v4i1.3550.

Jarmita, N. (2014). "Kesulitan Pemahaman Konsep Matematis Siswa Dalam Pembelajaran Matematika Di Kelas Awal Sekolah Dasar." PIONIR: Jurnal Pendidikan 4:1-16.

Mawaddah, S., \& Ratih, M. (2016). "Kemampuan Pemahaman Konsep Matematis Siswa SMP Dalam Pembelajaran Menggunakan Model Penemuan Terbimbing (Discovery Learning)." EDUMAT: Jurnal Pendidikan Matematika 4(1):76-85. doi: 10.20527/edumat.v4i1.2292.

Oktaviana, D. (2018). "Analisis Tipe Kesalahan Berdasarkan Teori Newman Dalam Menyelesaikan Soal Cerita Pada Mata Kuliah Matematika Diskrit." Edu Sains:
Jurnal Pendidikan Sains \& Matematika 5(2):22. doi: 10.23971/eds.v5i2.719.

Puspitasari, M., \& Rafiq, Z. (2021). "Analisis Kesalahan Siswa Kelas Vii Dalam Menyelesaikan Soal Cerita Berdasarkan Teori Newman Ditinjau Dari Aspek Problem Representation Dan Solution Execution." Jurnal Pembelajaran Matematika Inovatif 4(3):609-18. doi: 10.22460/jpmi.v4i3.609-618.

Rahmawati, D., \& Laelatul, D. P. (2018). "Analisis Kesalahan Siswa Dalam Menyelesaikan Soal Cerita Program Linear Dengan Prosedur Newman." Jurnal Elektronik Pembelajaran Matematika ISSN: 2339-1685

Http://Jurnal.Uns.Ac.Id/Jpm 5(2):173-85.

Rudtin, N. A. (2013). "Penerapan Langkah Polya Dalam Model Problem Based Instruction Untuk Meningkatkan Kemampuan Siswa." Jurnal Elektronik Pendidikan Matematika Tadulako 01(01):17-31.

Setyaningrum, V. F., Putriaji H., \& Sugeng Nugroho. (2018). "Peningkatan Pemahaman Konsep Dan Kerja Sama Siswa Kelas X Melalui Model Discovery Learning." Prisma 1:810-13.

Siahaan, M, . (2020). "Pendidikan Tinggi di Masa dan Pasca Covid19" Jurnal Kajian Ilmiah Edisi Khusus 1(1): 73-80

Siswandi, E., \& Imam S. (2016). "Analisis Kesalahan Siswa Damam Menyelesaikan Masalah Kontekstual Ditinjau Dari Perbedaan Gender ( Studi Kasus Pada Siswa Kelas VII SMPN 20 Surakarta )." Jurnal Elektronik Pembelajaran Matematika 4(7):633-43. 
DOI: https://doi.org/10.24127/ajpm.v10i4.4289

Sobana. (2020). "Dampak Pandemi Covid 19 Terhadap Pendidikan Dan Pelatihan Aparatur." Jurnal Pendidikan Indonesia 1(2):166-75. doi: 10.36418/japendi.v1i2.18.

Wulandari, D. P. (2012). "Siswa Sd Melalui Pembelajaran Dengan Pendekatan Problem Posing." Meningkatkan Pemahaman Konsep Matematika Siswa Sd Melalui Pembelajaran Dengan Pendekatan Problem Posing (2). 